\title{
WALKA O ZAPRZYSIĘŻENIE KONFEDERACJI WARSZAWSKIEJ OD 17 MAJA 1573 R. DO 22 KWIETNIA 1574 R. W ŚWIETLE „DIARIUSZA POLSKIEGO DO FRANCJI PO HENRYKA WALEZEGO W 1573 ROKU"
}

Streszczenie. Artykuł stanowi rekonstrukcję jednego z etapów walki o ujęcie w ramy formalno-prawne postanowień o tolerancji religijnej zawartych w spisanym w $1573 \mathrm{r}$. akcie konfederacji generalnej warszawskiej. Obejmuje czasy od elekcji Henryka Walezego (11 V 1573) do zakończenia obrad sejmu koronacyjnego tego króla (24 IV 1574). Artykuł składa się z trzech części. Wstępny fragment nakreśla jego cel, zawiera ponadto informacje o źródłach i literaturze. W rozwinięciu opisane zostały poszczególne wydarzenia związane $\mathrm{z}$ batalią o tolerancję religijną wraz z towarzyszącą im atmosferą oraz motywami i sposobem działania poszczególnych uczestników tych zajść. Zakończenie tekstu zawiera wnioski sformułowane na podstawie opisu.

Słowa kluczowe: Konfederacja warszawska, tolerancja religijna, Henryk Walezy, Kościół katolicki, Rzeczpospolita Obojga Narodów.

0 pisany w 1573 r. akt konfederacji generalnej warszawskiej miał na celu prawne uregulowanie najważniejszych dla Rzeczypospolitej Obojga Narodów kwestii na czas pierwszego bezkrólewia po śmierci Zygmunta Augusta. Niektóre z jego przepisów okazały się jednak na tyle znaczące, że batalia o ich uchwalenie toczyła się jeszcze przez szereg kolejnych lat. Mam tu na myśli zawarte w dokumencie postanowienia w kwestii tolerancji wyznaniowej. 
Chociaż tolerancja religijna w Polsce stanowiła wielowiekową tradycję, kwestia koegzystencji różnych wyznań w państwie polsko-litewskim była przedmiotem sporu. $\mathrm{W}$ walce o ujęcie artykułów tolerancyjnych w ramy formalno-prawne po jednej stronie barykady stanęli hierarchowie broniący interesów Kościoła katolickiego, po drugiej natomiast - wpływowi różnowiercy, szlachta oraz ta część katolickiego duchowieństwa, która ponad interes Kościoła przedkładała utrzymanie pokoju wewnątrzpaństwowego.

Celem niniejszego artykułu jest rekonstrukcja na podstawie wybranych źródeł wydarzeń wynikających z batalii o zaprzysiężenie artykułów o tolerancji religijnej zapisanych $\mathrm{w}$ akcie konfederacji generalnej warszawskiej w okresie od elekcji Henryka Walezego do zakończenia obrad sejmu koronacyjnego z $1574 \mathrm{r}$.

Do naszych czasów zachowało się sporo źródeł opisujących walkę o uchwalenie konfederacji warszawskiej. Do zredagowania niniejszego artykułu posłużył przede wszystkim Diariusz poselstwa polskiego do Francji ${ }^{1}$. Jest to wyjątkowe źródło, które nie tylko ze szczegółami opisuje działalność delegacji, lecz także oddaje atmosferę towarzyszącą jej misji. Ukazuje poglądy i osobowość poszczególnych deputatów oraz ich stosunek do konkretnych spraw politycznych. Z tych właśnie powodów diariusz pozwala spojrzeć na misję poselstwa oczyma jej uczestników i w ten sposób nadaje niepowtarzalny wymiar opisowi badanego problemu.

Batalia o uchwalenie wspomnianych postanowień konfederacji warszawskiej toczyła się od momentu jej pierwszego spisania (28 stycznia 1573 r.) do chwili zaprzysiężenia aktu przez Stefana Batorego i wyniesienia go do rangi konstytucji sejmowej ${ }^{2}$. Należyte opracowanie tak rozległego tematu w jednym artykule jest więc niemożliwe. Z uwagi na to właściwym przedsięwzięciem jest wyznaczenie poszczególnych etapów walki o legitymizację tolerancji wyznaniowej w oparciu o istotne wydarzenia polityczne. Bezkrólewia, okresy rządów poszczególnych władców oraz sejmy były w dziejach Rzeczpospolitej momentami przełomowymi i z tego powodu mogą pełnić funkcję wyznaczników cezury czasowej.

W czterdziesty trzeci dzień sejmu elekcyjnego (niedziela 17 maja 1573 r.) po porannej Mszy Świętej odbyła się narada senatorów. Ustalono na niej skład poselstwa, które miało zawieźć do Paryża dekret elekcyjny wraz z oficjalną wiadomością o wyborze Henryka Walezego na króla Rzeczpospolitej. Trzy dni później obrady sejmu dobiegły końca. Senatorowie zaczęli opusz-

${ }^{1}$ Diariusz poselstwa polskiego do Francji po Henryka Walezego w 1573 roku, oprac. A. Przyboś, R. Żelewski, Wrocław-Warszawa-Kraków 1963.

${ }^{2}$ M. Korolko, J. Tazbir, Konfederacja warszawska 1573 roku. Wielka karta polskiej tolerancji, Warszawa 1980, s. 55. 
czać Warszawę, a podkanclerzy Franciszek Krasiński ówczesny biskup krakowski, został tam, aby przygotować potrzebne posłom dokumenty.

Instrukcja dana przez niego deputatom nie zawierała zapisu o sporze wokół postanowień konfederacji warszawskiej, lecz jedynie postulat, by elekt we własnym imieniu potwierdził przyrzeczenia złożone przez jego delegatów na sejmie elekcyjnym ${ }^{3}$. W przypadku odmowy członkowie poselstwa polsko-litewskiego mieli zagrozić brakiem ze strony stanów Rzeczypospolitej spełnienia obowiązków względem niego ${ }^{4}$. Szantaż ów mógł okazać się korzystny dla zwolenników konfederacji, którzy w trakcie sejmu elekcyjnego wymusili na francuskiej delegacji zaprzysiężenie artykułów tolerancyjnych ${ }^{5}$.

Fragment instrukcji z takim zapisem Krasiński przesłał w formie sekretnego pisma późniejszemu przewodniczącemu poselstwa, biskupowi poznańskiemu - Adamowi Konarskiemu. Kopii dokumentu zażądał także prymas - Jakub Uchański. Autor instrukcji - Andrzej Patrycy Nidecki nie spełnił jednak prośby duchownego, przedłożywszy mu jedynie streszczenie dokumentu. Uchański i nuncjusz apostolski - Giovanni Francesco Commendone, otrzymali ponadto list wierzytelny. Wysłannik papieski sprzeciwiał się zawarciu w nim niektórych wyrażeń. Dotyczyło to w szczególności sformułowania In solidum ${ }^{6}$, które uznał za uprawniające każdego posła $\mathrm{z}$ osobna do zawarcia porozumienia z elektem. Opinii nuncjusza, co w owym czasie zdarzało się niezwykle rzadko, nie podzielał arcybiskup gnieźnieński, twierdząc, iż żaden członek poselstwa nie ma prawa do przeforsowania interesujących go postulatów indywidualnie. Sformułowanie In solidum prymas uznał za konieczne. Według niego pozwalało ono delegacji jako całości nawiązać porozumienie z elektem w wypadku, gdyby wyjazd do Francji któregokolwiek z jej członków okazał się niemożliwy. W walce o wyrażenie Commendonego poparł włoski teolog katolicki - Giovannii Maria Tolosani, który zaproponował umieszczenie w tekście innego sformułowania, zastrzegającego prawomocność układów zawartych tylko przez posłów obecnych przy wypracowywaniu warunków porozumienia. Uchański poparł propozycję teologa i zlecił swemu sekretarzowi przygotowanie dla posłów odpowiedniego pełnomocnictwa7. Nowy list pełnomocny zawierał zredagowaną

3 Sumariusz instrukcji posłom do Francyi, T. Wierzbowski, Uchańsciana czyli zbór dokumentów wyjaśniających życie i działalność Jakuba Uchańskiego arcybiskupa Gnieźnieńskiego, legata urodzonego Królestwa Polskiego prymasa i pierwszego księcia, T. 4, Warszawa 1992, s. 283-284.

${ }^{4}$ Diariusz poselstwa polskiego do Francji..., s. 10-16.

5 Tamże, s. 17-18.

${ }^{6}$ In solidum - łac. w postaci stałej.

7 T. Wierzbowski, Jakub Uchański arcybiskup gnieźnieński (1502-1581), Warszawa 1895, s. 540-541. 
przez arcybiskupa gnieźnieńskiego protestację. Duchowny oznajmił w niej, iż wyrazi zgodę tylko na te postanowienia, które nie naruszą praw królewskich, przywilejów stanowych oraz pozycji wyznania rzymskokatolickiego.

Jean de Monluc - przewodniczący francuskiego poselstwa na sejm 1573 r., był świadom, iż prymas ma na myśli konfederację warszawską. Arcybiskup gnieźnieński bowiem powiadomił go wcześniej o zamiarze podjęcia działań w celu udaremnienie zaprzysiężenia przez Walezego artykułów o pokoju religijnym. Chcąc wprowadzić owo postanowienie w czyn, Uchański zasugerował Commendonemu, by poinformował on o sprawie nuncjusza apostolskiego działającego we Francji. Sam natomiast wysłał tam swoich współpracowników ${ }^{8}$.

Pomimo trudności $w$ nawiązaniu porozumienia $w$ sprawie instrukcji udało się wreszcie ustalić skład polsko-litewskiego poselstwa. Jak już zostało wspomniane, przewodniczył mu biskup Konarski. Poza nim w skład delegacji weszło jeszcze czterech katolików z Korony (Olbracht Łaski, Jan Herburt, Stanisław Kryski i Jan Zamoyski). Reprezentacja koronna zawierała także wyznawców luteranizmu (Jan i Mikołaj Tomicy, Andrzej Górka oraz Jan Zborowski). Jedyny zaś w poselstwie reprezentant Wielkiego Księstwa Litewskiego - Mikołaj Krzysztof Radziwiłł, był kalwinistą. Nieznana jest natomiast ówczesna przynależność wyznaniowa pozostałych deputatów: Jana Tęczyńskiego i Mikołaja Firleja.

Jak możemy zauważyć, osobowy skład poselstwa jest pewnego rodzaju odzwierciedleniem układu sił w Rzeczpospolitej zarówno w aspekcie wyznaniowym, jak również społeczno-politycznym ${ }^{9}$. W obliczu takiej różnorodności trudno o zgodę i wzajemne zaufanie. Ludzie, którzy podczas sejmu obradowali w sprawach poselstwa, niewątpliwie byli tego świadomi. Może o tym świadczyć jedna z podjętych wówczas uchwał, wprost nakazująca zgodne współdziałanie posłów. Natomiast list wierzytelny zawierał postanowienie, że tylko układy z elektem zawarte w obecności wszystkich deputatów mogą być prawomocne. Większość tych postulatów została zrealizowana, gdyż pomimo braku wzajemnego zaufania posłowie zazwyczaj działali zgodnie. Wyjątek od tej reguły stanowiła sprawa tolerancji wyznaniowej ${ }^{10}$.

Biskup A. Konarski, podobnie jak Uchański i Commendone, sprzeciwiał się postanowieniom tolerancyjnym. Zarówno nuncjusz jak i prymas usiłowali nakłonić przewodniczącego poselstwa, aby stanął w opozycji do artykułów o pokoju religijnym. Jednakże usiłowania duchownych spełzły na niczym za sprawą przyjęcia instrukcji oraz zaprzysiężenia przez delegację

\footnotetext{
${ }^{8}$ S. Płaza, Wielkie bezkrólewia, Kraków 1988, s. 23.

9 Tamże, s. 22.

10 Tamże, s. 23.
} 
francuską artykułów henrykowskich drugiej reakcji ${ }^{11}$, które nakazywały odmienne działania. W zaistniałych okolicznościach wchodzący w skład deputacji protestanci posiadali wystarczające podstawy prawne do przeforsowania swych postulatów.

Jako hierarcha katolicki Konarski obawiał się kompromitacji w oczach Stolicy Apostolskiej. Dlatego oczekiwał od Uchańskiego i Commendonego wskazówek co do dalszego postępowania. Świadczy o tym korespondencja, którą kierował do obu duchownych. Nie czekając na odpowiedź biskup nakreślił swe wątpliwości kanonikowi poznańskiemu - Albertowi Stanisławskiemu, prosząc go o wypowiedź w spornej kwestii. Niepewność Konarskiego dotyczyła dokumentów odnoszących się do misji poselstwa. Żywił bowiem obawy czy okażą się one wystarczające. Problem ten wynikał z odebrania przez dwa zwaśnione obozy podwójnej przysięgi od francuskich posłów. Konarski zastanawiał się nad ewentualnymi trudnościami w wypracowaniu układów z elektem, które mogły wystąpić w wyniku zaistniałej sytuacji. Rozmyślał, co jako poseł powinien uczynić, gdyby takie problemy się pojawiły. Sprawę dodatkowo komplikował fakt występowania pod różnowierczymi postulatami pieczęci dwóch biskupów. Duchowny radził się ponadto kanonika w kwestii wyboru dogodnego momentu dla wystąpienia z protestacją przeciwko artykułom tolerancyjnym. Zapytał również co powinien uczynić, gdyby poselstwo nie otrzymało pozwolenia na przejazd przez Cesarstwo. Konarski zabiegał w owym czasie u prymasa o przysłanie mu do pomocy prałatów. Prosił go ponadto o sugestie co do sposobu przeprowadzenia misji tak, aby nie dopuścić do jakiegokolwiek skandalu. Takie postępowanie biskupa wynikało ze świadomości ewentualnej konieczności wystąpienia przeciwko pozostałym posłom i szykan w kraju mogących stanowić następstwo tego typu działań.

Uchański i Commendone przebywali w Skierniewicach, gdy w połowie czerwca 1573 r. otrzymali od Konarskiego memoriał z zapytaniami dotyczącymi ww. problemów. Jakiś czas później do Skierniewic przybył również biskup kujawski - Stanisław Karnkowski. Hierarchowie naradzili się, po czym odpowiedzieli Konarskiemu. Z uwagi na pieczęć oraz podpis prymasa duchowni uznali za prawomocne dokumenty dotyczące poselstwa wraz z protestacją przeciwko konfederacji warszawskiej. W kwestii zaś postulatów różnowierczych spisanych przez obóz Jana Firleja poradzili biskupowi poznańskiemu, by uznał je za nieistniejące. Zalecili mu także protestowanie przeciwko nim z uwagi na brak przy ich zredagowaniu zgody reprezentantów wszystkich stanów. Sugerowali wnoszenie zarówno publicznych, jak też prywatnych protestacji, kiedy tylko będzie to możliwe. Znaleźli również

11 Patrz dalsza część artykułu. 
rozwiązanie kwestii podpisu dwóch biskupów pod artykułami dysydentów. Zalecili Konarskiemu, żeby oznajmił, iż zostały one złożone bez dostatecznego namysłu. Zgodnie z opinią duchownych przywódca deputacji powinien był także zakwestionować słuszność brania pod uwagę zdania dwóch hierarchów w obliczu faktu wystąpienia ich w mniejszości wobec opinii pozostałych. Uchański zamierzał ponadto spełnić prośbę Konarskiego o delegatów do pomocy. Poprosił więc biskupa krakowskiego o wyznaczenie do tej misji Wojciecha Brudzyńskiego lub Marcina Rusieckiego. Usiłował także nakłonić obu prałatów, by któryś z nich zgodził się na wyjazd do Francji. Prymas zapewnił poza tym iż przejazd przez Cesarstwo nie zostanie poselstwu odmówiony. Jeżeli zaś chodzi o ewentualny skandal bądź szykany, Uchański stwierdził, że wyparcie się bronionej dotychczas sprawy stanowiłoby skandal znacznie większy. Tłumaczył ponadto, zresztą słusznie, że wszyscy przeciwnicy artykułów tolerancyjnych są narażeni na nieprzyjemności tak samo jak przywódca delegacji.

Pomimo wsparcia ze strony prymasa biskup poznański nie zaznał spokoju. Jeszcze bowiem przed podróżą dowiedział się o prowadzonej przez dysydentów agitacji, mającej na celu zdobycia poparcia, które mogłoby zwiększyć szanse powodzenia ich misji we Francji. Jedno z przedsięwzięć protestantów stanowiło poruszenie sprawy tolerancji na zwołanych we wrześniu 1573 r. sejmikach wojewódzkich. Wskutek tego pod aktem konfederacji warszawskiej zebrano blisko 2500 podpisów. Protestantom sprzyjał fakt zabrania do Paryża zaprzysiężonych wobec Firleja artykułów henrykowskich drugiej redakcji.

W zaistniałej sytuacji zapewnienia prymasa nie wydawały się Konarskiemu dostateczne. Zaczął więc posądzać katolickie stronnictwo o obojętność oraz lekceważące podejście do sprawy zagrożenia interesów Kościoła. Przewodniczący poselstwa nie dał za wygraną. Wysłał do Commendonego i Uchańskiego Stanisławskiego z drugim memoriałem. Zawierał on prośbę o skuteczne przeciwstawienie się działalności zwolenników tolerancji, a także o dokładne informacje w tej sprawie.

Odpowiedź arcybiskupa gnieźnieńskiego na memoriał niestety nie zachowała się do naszych czasów. Z ówczesnych przekazów wiemy tylko, że Uchański polecił Konarskiemu, by podczas podróży nie nawiązał z dysydentami porozumienia. Zgodnie z życzeniem przełożonego biskup miał także w odpowiednim momencie zaprotestować w Paryżu przeciwko postulatom protestantów w imieniu wszystkich biskupów i wszystkich katolików ${ }^{12}$.

12 T. Wierzbowski, Jakub Uchański..., s. 542-544. 
Deputacja przybyła do Paryża 20 sierpnia 1573 r. Jej przywódca rozpoczął działanie od odczytania posłom instrukcji ${ }^{13}$. Już dwa dni później miało miejsce lekkie poruszenie spraw wyznaniowych. Wtedy do członków delegacji przemówił król Francji - Karol IX. Monarcha podziękował stanom Rzeczypospolitej za elekcję brata. Następnie oświadczył, iż wraz ze swoim narodem chce mieć dobre relacje z państwem polsko-litewskim. Stwierdził, że połączenie obu krajów jedną dynastią panującą przyniesie pożytek zarówno Rzeczypospolitej, jak również chrześcijaństwu ${ }^{14}$. To wbrew pozorom znaczące słowa, jeśli weźmiemy pod uwagę fakt, że wypowiedział je władca, który rok wcześniej zezwolił na krwawą rzeź przedstawicieli innego wyznania w stolicy swego królestwa (tzw. Noc św. Bartłomieja). W mowie Karola IX widzimy także próbę uspokojenia tych, którzy obawiali się o swoje wolności czy przywileje. Zapewnił on bowiem, że jego młodszy brat zachowa w Rzeczypospolitej dotychczasowe prawa.

Biskup Konarski podziękował królowi za przemówienie i wyraził nadzieję, iż Henryk Walezy będzie panował tak, jak wypada to czynić chrześcijańskiemu władcy ${ }^{15}$. Jeśli słowa te zestawimy z poglądami hierarchy dotyczącymi konfederacji warszawskiej, nasuwa się teza, że duchowny miał na myśli konieczność sprzeciwu elekta wobec uchwalenia artykułów tolerancyjnych.

Bez wątpienia w trakcie misji poselstwa sprawy wyznaniowe Rzeczypospolitej rodziły wśród jego członków obawę braku zgody. Widać to chociażby w relacji z 25 sierpnia, która podaje, iż

Tegoż dnia namawialiśmy o artykułach, abyśmy zgodnie o nich przed Panem naszym rozumieli. Na któreśmy się wszyscy zgodzili przy nich mocnie stać, jako są napisane in toto, ani w czym nie odmieniać ${ }^{16}$.

Dzień później Henryk Walezy zaprosił deputatów na audiencję. Miały podczas niej zapaść postanowienia dotyczące artykułów henrykowskich. Pojawiło się wtedy pytanie czy oddać elektowi tylko artykuły pierwszej redakcji, czy również te, spisane przez stronników Firleja. Ostatecznie zadecydowano o odłożeniu sprawy drugich artykułów na inny czas, Posłowie chcieli bowiem jeszcze się w tej kwestii naradzić, gdyż nie zostały one dotychczas wspólnie odczytane.

Na początku audiencji do elekta przemówił A. Konarski. Wytłumaczył, że posłowie nie przekazali swych postulatów delegacji francuskiej, ponieważ

\footnotetext{
${ }^{13}$ Diariusz poselstwa polskiego do Francji..., s. 10.

14 Tamże, s. 124.

15 Tamże.

16 Tamże, s. 126.
} 
uznali, za stosowne osobiście przedłożyć je Walezemu. Oznajmił też, iż oprócz przyniesionych artykułów poselstwo posiada jeszcze inne, ale z powodu potrzeby naradzenia się co do nich przedstawi je w innym terminie. Po przeczytaniu artykułów pierwszej redakcji monarcha miał pewne obiekcje co do przepisu o niemożności rezydowania na jego dworze Francuzów. Zgodził się jednak zatwierdzić przyniesione postanowienia.

Artykuły drugiej redakcji zostały przedłożone elektowi 28 sierpnia. Zgromadzeni wspólnie je odczytali, po czym Konarski poprosił Walezego o audiencję. Podczas niej zaprotestował przeciwko postanowieniom tolerancyjnym w imieniu własnym, wszystkich kapituł, biskupów oraz całego duchowieństwa Rzeczypospolitej. Oświadczył, iż tak, jak nie zgadzali się oni na postanowienia konfederacji warszawskiej podczas konwokacji oraz sejmu elekcyjnego, tak również nie zgadzają się na nie obecnie. Następnie pokazał elektowi pismo przeciwko postanowieniom o pokoju religijnym, zredagowane w imieniu prymasa, biskupów, a także części świeckich katolickich dostojników, którzy oprotestowali nie tylko samą konfederację, ale też prowadzoną w jej obronie działalność marszałka Firleja. Konarski przedłożył również elektowi opieczętowaną i podpisaną własnoręcznie przez J. Uchańskiego plemipotencję.

Po zakończeniu przemowy przez biskupa głos zabrał Olbracht Łaski. Wojewoda sieradzki stwierdził, iż podpisał konfederację warszawską nie dlatego, że się z nią zgadza, lecz ponieważ był świadom, że uchwała o tolerancji wyznaniowej zapewni pokój w kraju. Oznajmił ponadto, że nie może pozwolić na swobodne szerzenie się sekt na terytorium państwa polsko-litewskiego i stanowczo zaprotestował przeciwko takiej ewentualności, oprotestowując przy tym zredagowane przez Firleja artykuły tolerancyjne.

Po wygłoszeniu obu protestacji przemówił Jan Zborowski - kasztelan gnieźnieński. Oświadczył, że kiedy francuscy posłowie zaprzysięgli artykuły drugiej redakcji, nie protestował przeciwko temu nikt poza kilkoma duchownymi. Na tej podstawie stwierdził, iż przedstawiciele wszystkich stanów zgodzili się na przyjęcie postulatów sformułowanych przez stronnictwo Firleja. W związku z tym zasugerował Walezemu, że może bez obaw je zaprzysiąc. Opinię kasztelana podzielali również kniaź Aleksander Proński oraz kasztelan międzyrzecki - Andrzej Górka. Marszałek litewski - Mikołaj Krzysztof Radziwiłł, także opowiedział się za konfederacją, ponieważ, podobnie jak Łaski twierdził, że zapewni ona pokój wewnątrzpaństwowy. Za tolerancją wyznaniową optowali również starostowie: kazimierski (M. Firlej) i bełski (J. Zamoyski), kasztelan sanocki (J. Herburt), a także M. Tomicki. Znajdujący się $\mathrm{w}$ tej grupie katolicy oświadczyli przy tym, iż mimo aprobaty dla tolerancji wyznaniowej nie zamierzają odstąpić od wiary Następnie zwrócili się 
do elekta z prośbą o zaprzysiężenie artykułów o pokoju religijnym. Starosta kazimierski zauważył wówczas, że jednym z sygnatariuszy protestacji przedłożonej przez Konarskiego, miał być rzekomo jego ojciec, wojewoda krakowski - Jan Firlej. Syn wojewody nie wierzył w to i prosił przyszłego króla, by on również nie dał temu wiary. Natomiast kasztelan gnieźnieński przypomniał, iż podczas zaprzysięgania konfederacji przez posłów francuskich nikt jej nie oprotestował, zasugerował przy tym elektowi, by ten sam zapytał o to członków swojej deputacji.

Odpowiadając na te sugestie, J. de Monluc oznajmił, że po tym jak wraz z towarzyszami zaprzysiągł pierwsze artykuły, marszałek wielki koronny (J. Firlej) przedłożył mu postulaty drugiej redakcji. Przewodniczący poselstwa francuskiego wyraził pragnienie zaprowadzenia w nich zmian (miał na myśli jeden artykuł, lecz wówczas nie powiedział który). Kiedy jednak Firlej nie zgodził się na jego propozycję, delegacja francuska zaprzysięgła artykuły drugiej redakcji. Francuzi obawiali się bowiem eskalacji międzywyznaniowego konfliktu. Dalej Monluc mówił, iż podczas składania przysięgi nie protestowali ani senatorowie, ani szlachta. Jako jedynego oponenta Francuz wskazał arcybiskupa gnieźnieńskiego.

Po wysłuchaniu Monluca poselstwo Rzeczypospolitej usiłowało skłonić elekta do przeczytania formuły przysięgi drugiej redakcji. Henryk Walezy naradził się nad nią ze swymi doradcami, po czym oświadczył, iż sprawę tę odłoży do jutra (do dnia 30 sierpnia). Ostatecznie jednak odwlekł odpowiedź jeszcze o dzień.

31 sierpnia do deputatów z Rzeczypospolitej przybyli wysłannicy Walezego. Przez nich przekazał on, że niczego bardziej nie pragnie dla kraju niż pokoju i zgody. Oświadczył, iż byłby rad zaprzysiąc artykuły tolerancyjne dla zachowania całości państwa. Jednakże protestacje duchowieństwa, kapituł oraz niektórych świeckich dostojników wzbudziły w nim wątpliwości. Elekt nie był pewien, po której stronie się opowiedzieć. Zaproponował więc, by stany Rzeczypospolitej osiągnęły porozumienie w kwestii tolerancji wyznaniowej. Obiecał przy tym zaprzysiężenie na sejmie koronacyjnym tego, co zostanie uzgodnione.

Posłowie odpowiedzieli, iż ewentualna decyzja o odłożeniu przysięgi nie leży w ich gestii. Wyjaśnili, że nikt ze stanów świeckich nie wystąpił przeciwko tolerancji. W kwestii zaś przedłożonej Walezemu noty protestacyjnej w imieniu posłów wypowiedział się kasztelan sanocki. Uznał iż nie ma ona znaczenia, ponieważ została zredagowana w ukryciu i naprędce, a dokumenty stworzone w taki sposób nie posiadają w Rzeczypospolitej mocy prawnej. Za pośrednictwem współpracowników przyszłego monarchy posłowie próbowali przekonać go, by nie brał pod uwagę prywatnej protestacji. J. Herburt 
ponownie poprosił, aby Walezy zaprzysiągł artykuły o pokoju religijnym uspokajając, że nie wywoła to w Rzeczypospolitej żadnego tumultu. Nie przekonało to jednak wysłanników elekta, którzy naradziwszy się odeszli pozostawiając sprawę do rozstrzygnięcia na inny czas.

Biskup Konarski nie dał za wygraną. Na odbytym 1 września spotkaniu z przyszłym królem podtrzymał swoje zdanie o konfederacji, utrzymując także protest kapituł i duchowieństwa. Jeżeli zaś chodzi o pozostałe artykuły, to podobnie jak inni posłowie, wyraził na nie zgodę.

W odpowiedzi Walezy oświadczył, iż cieszy go zgoda członków delegacji co do pozostałych postanowień. Życzył im również wypracowania porozumienia w sprawie tolerancji wyznaniowej.

Usłyszawszy od elekta taką odpowiedź, posłowie oddalili się na naradę. Prosili biskupa poznańskiego o wycofanie protestacji. Duchowny ich nie posłuchał i po powrocie przed oblicze Walezjusza oświadczył, iż podtrzymuje dotychczasowe stanowisko. Dodał, że nie sprzeciwia się pozostałym zapisom. Zasugerował ponadto, by elekt potwierdził wszystkie artykuły poza postanowieniami o tolerancji religijnej. Starosta bełski natomiast zaapelował o złożenie przysięgę bez względu na protestację. W odpowiedzi Walezy porozumiał się ze swą radą, po czym oznajmił, że potwierdzi wszystkie artykuły.

Nie oznaczało to jednak końca batalii o przysięgę. 9 września w czasie kolejnego spotkania poselstwa z elektem rozgorzał spór o to kto ma odczytać jej osnowę. Nieporozumienie wynikało z faktu, iż A. Konarski nie chciał odczytać formuły zawierającej artykuły o tolerancji wyznaniowej. Wobec tego posłowie zdecydowali, że formułę odczyta Herburt. Termin złożenia przysięgi wyznaczono na kolejny dzień. 10 września elekt zaprzysiągł w Paryżu artykuły henrykowskie i pacta conventa, kończąc tym samym toczący się wokół nich spór ${ }^{17}$.

Wydarzenie to znacznie przechyliło szalę zwycięstwa na stronę różnowierców. Zwolennicy tolerancji nie tracili czasu, prowadząc dalszą agitację w celu zdobycia poparcia. Zwołane na początku września 1573 r. sejmiki: wielkopolski w Środzie i małopolski w Proszowicach opowiedziały się za pokojem religijnym. Protestanci zwołali ponadto w owym czasie synody w Poznaniu oraz Krakowie. Zastanawiali się podczas nich jakie działania powinni podjąć w celu ochrony swych praw.

Sytuację bacznie obserwował prymas, który dla zasięgnięcia informacji wysłał do Proszowic i Środy swoich współpracowników. Nakłaniał on ponadto do podjęcia kontrofensywy uczestniczących w obradach katolików.

17 Tamże, s. 163-169. 
Na wezwanie arcybiskupa gnieźnieńskiego odpowiedział Marcin Izdbieński, który w imieniu kapituły krakowskiej protestował przeciwko artykułom o pokoju religijnym na sejmiku proszowickim. Podobnie uczynili uczestnicy sejmiku płockiego, zwołanego do Raciąża na 1 września. Sformułowali oni uroczystą protestację przeciwko postanowieniom tolerancyjnym. Na apel Uchańskiego i Karnkowskiego odpowiedzieli również mazowszanie na sejmiku obradującym w Warszawie w listopadzie 1573 r. Oświadczyli, że nie zgadzają się na zatwierdzenie aktu konfederacji generalnej, stwierdzając, iż Walezy zapewne nie zaprzysiągł jej dobrowolnie.

Zdecydowane działania podjął również kardynał Stanisław Hozjusz, który na wieść o złożonej przez elekta przysiędze napisał do Karnkowskiego list z prośbą o niedopuszczenie do jej powtórzenia w Krakowie. Podobne polecenie przekazał również Uchańskiemu. W instrukcji adresowanej do arcybiskupa gnieźnieńskiego kardynał Hozjusz nazwał konfederację warszawską nikczemnym spiskiem, zawiq̨zanym przeciwko Chrystusowi ${ }^{18}$.

Tymczasem nuncjuszem apostolskim w Rzeczypospolitej został Wincenty Laureo, który był świadkiem przysięgi złożonej przez elekta w Paryżu. Nowy wysłannik Stolicy Apostolskiej umyślnie wyprzedził Walezego w drodze do kraju. Zamierzał bowiem przygotować podatny grunt pod kontrofensywę przeciwko postulatom dysydentów.

Kiedy powracająca z Francji wraz z elektem delegacja przekroczyła Ren, Uchański udał się do Frankfurtu nad Odrą z zamiarem wyjścia naprzeciw nadjeżdżającym. Chciał zrelacjonować Walezemu sytuację panując w państwie. Zamierzał również udzielić przyszłemu władcy stosownych, według jego mniemania, rad odnośnie postępowania w kwestiach wyznaniowych.

18 lutego 1574 r. Walezy przybył do Krakowa ${ }^{19}$. Dzień później rozgorzała dyskusja, czy powinien on wydać ogólne potwierdzenie przywilejów koronnych: przed, czy po koronacji. Część elit optowała za pierwszym wariantem. Stronnictwo katolickie wyraziło jednak przeciwne zdanie. Zwolennicy konfederacji nie zamierzali się poddać. Dla osiągnięcia celu niektórzy zdolni byli nawet do kłamstwa czy innego rodzaju nieczystych zagrywek. Świadczy o tym następująca relacja, podana przez dziewiętnastowiecznego dziejopisa - Teodora Wierzbowskiego:

Wśród rozpraw Abraham Zbąski, chcąc prymasa usunąć z senatu, krzyknął, że dom jego się pali. Uchański niezmieszany rozkazał służbie tłumić pożar

${ }^{18}$ Instructio IIImi Varmiensis data Joanni Rembiliański de tractandis cum archiepiscopo Gnesnense, [w:] T. Wierzbowski, Uchańsciana..., s. 290-296.

19 J. Bielski, Kronika polska Marcina Bielskiego. Księgi VI Interregnum, T. XVIII, cz. 6, Warszawa 1632, s. 157. 
i Zbąskiemu chwilę polecił się zatrzymać, mówiąc, że ma o daleko większym pożarze rozprawiać, do którego ugaszenia siła pracy ciężkiej użyć potrzeba ${ }^{20}$.

Ten „większy pożar” według prymasa zagrażał całemu krajowi, a stanowiły go wynikające z obowiązującego prawa nieporozumienia i niepewność. Przekaz ten nie pozostawia wątpliwości. Arcybiskup gnieźnieński mimo iż wykazywał nie lada upór w sprawie artykułów tolerancyjnych, zdawał sobie sprawę z zagrożenia dla wewnętrznego bezpieczeństwa państwa, które mógłby przynieść brak porozumienia w kwestii swobód religijnych.

Osiągnięcie kompromisu było jednak niezwykle trudne. Spór o formułę przysięgi, którą król miał powtórzyć w momencie koronacji, toczył się jeszcze dzień przed uroczystością. W batalii tej stronie katolickiej przewodził nuncjusz Laureo, który, podobnie jak jego poprzednik, miał ogromny wpływ na prymasa ${ }^{21}$.

Arcybiskup gnieźnieński chciał zapewne uspokoić nastroje apelując, aby przed koronacją podejmowano dyskusje tylko w sprawach ściśle z nią związanych. Pozostałe kwestie zalecał natomiast odłożyć do pierwszego zwołanego przez monarchę sejmu. Protestanci jednak nie posłuchali próśb prymasa. W przeddzień uroczystości nadal usilnie nalegali, by Walezy zatwierdził konfederację warszawską. W tej sytuacji wiedziano więc, iż niewyciszony konflikt może zakłócić przebieg ceremonii.

Taki stan rzeczy nie odpowiadał Henrykowi Walezemu, który usiłował wpłynąć na Piotra Zborowskiego oraz innych dysydenckich przywódców, by zaprzestali swych przedsięwzięć. Podobny apel pod adresem protestantów wystosował także Laureo.

P. Zborowski w porozumieniu ze swymi stronnikami zdecydował się pójść na pewne ustępstwa. Oznajmił, że jego obóz nie będzie domagał się powtórzenia złożonej w Paryżu przysięgi pod warunkiem dodania do jej pierwotnej osnowy słów „zachowam i utrzymam pokój i zgodę między różniącymi się w wierze"22.

Początkowo prymas i biskupi gotowi byli przystać na taki kompromis. Nuncjusz apostolski pouczył ich jednak, że zaproponowana formuła byłaby tożsama z uznaniem tolerancji wyznaniowej. Wskutek tego hierarchowie zmienili zdanie, a Zborowski oświadczył, że w wypadku braku zgody duchownych na jego propozycję zwolennicy tolerancji zaczną ponownie domagać się powtórzenia drugiej roty przysięgi. Wobec tego wysłannik Stolicy Piotrowej ustąpił. Zobowiązał przy tym Uchańskiego do zaprotestowania w imieniu

\footnotetext{
20 T. Wierzbowski, Jakub Uchański..., s. 549.

${ }^{21}$ J. Bielski, dz. cyt., s. 162.

22 T. Wierzbowski, Jakub Uchański..., s. 550.
} 
całego duchowieństwa przeciwko dodatkowi do przysięgi. Prymas miał uzasadnić swój protest stwierdzeniem, iż dodane słowa są sprzeczne $\mathrm{z}$ formułą zawartą w statucie Łaskiego, a także, iż stoją w sprzeczności z chwałą Boga. Pomimo to osiągnięto porozumienie w sprawie przebiegu ceremonii.

W dniu koronacji Walezego arcybiskup gnieźnieński odprawił uroczystą Mszę Świętą w katedrze w Krakowie. Następnie odebrał od elekta przysięgę złożoną według roty z ceremoniarza koronacyjnego. Pomiędzy odśpiewaniem litanii a namaszczeniem świętymi olejami monarcha złożył zaś przysięgę według osnowy ze statutu Łaskiego. Kiedy to nastąpiło, przystąpili do Henryka wojewodowie wileński, sandomierski oraz krakowski prosząc, by powtórzył przysięgę drugiej redakcji. Uchański zaprotestował przeciwko takiemu rozwiązaniu, a złożenie kolejnej przysięgi uznał za zbyteczne. Znajdujący się w prezbiterium dysydenci poparli swoich przywódców i w świątyni zapanowało zamieszanie. Sytuację próbował uspokoić Jan Chodkiewicz, który zaproponował protestantom, aby poprzestali na poręczeniu, że król zachowa w kraju pokój religijny. Wówczas Walezy głośno wypowiedział słowa: „będę się starał zachować”23, na co biskup Karnkowski odpowiedział: „z zachowaniem praw należnych duchowieństwu”24. Ten pozorny kompromis uciszył niepokój, dzięki czemu dalsza część uroczystości przebiegła bez przeszkód ${ }^{25}$.

Tego samego dnia zredagowano akt dotyczący przebiegu koronacji. Pojawił się w nim zapis, iż monarcha złożył jedynie przysięgę według roty ze statutu. Na prośbę arcybiskupa gnieźnieńskiego zaświadczenie o takiej właśnie treści wydał również sam król, cytując przy tym osnowę statutowej przysięgi. Jeżeli zaś chodzi o dodatkowe wypowiedziane przez władcę słowa, w środowisku katolickim uważano, że skoro on je wymówił, posiada niezbywalne prawo do ich interpretacji.

Taki obrót spraw wydawał się pomyślny dla nuncjusza apostolskiego. Jednakże do pełni sukcesu brakowało całkowitego uwolnienia monarchy od konieczności zatwierdzenia artykułów tolerancyjnych. Żeby osiągnąć ów cel Laureo postanowił doprowadzić do zerwania sejmu. Zamierzał to uczynić za pośrednictwem mazowieckich posłów, a także biskupów z prymasem na czele. Nuncjusz działał niezmiernie ostrożnie, a działalność tę charakteryzowały przede wszystkim dwa środki. Pierwszy z nich to porozumiewanie się z Uchańskim za pośrednictwem innych osób. Drugi natomiast polegał na inicjowaniu pozornie przypadkowych spotkań z arcybiskupem w świątyni.

23 Tamże, s. 551.

${ }^{24}$ E. Dubas-Urwanowicz, Koronne zjazdy szlacheckie $w$ dwóch pierwszych bezkrólewiach po śmierci Zygmunta Augusta, Białystok 1998, s. 311.

25 J. Bielski, dz. cyt., s. 163. 
Laureo sprzyjało również powszechne zainteresowanie sprawą zabójstwa Andrzeja Wapowskiego, która odwróciła uwagę od jego działalności. Nuncjusz starał się nie uczestniczyć w spowodowanym tym wydarzeniem niepokoju politycznym ${ }^{26}$.

Przestępstwo i kwestie z nim związane sprawiły, że pozostałe sprawy zostały odsunięte na plan dalszy. Dopiero, gdy sprawca zbrodni - Samuel Zborowski, otrzymał wyrok, adresowane do króla prośby o zatwierdzenie przywilejów koronnych rozbrzmiały z nową siłą.

Aby nie dopuścić do potwierdzenia swobód wyznaniowych, 17 marca 1574 r. inspirowani przez nuncjusza posłowie mazowieccy wnieśli protestację. Oznajmili, że przybyli do Krakowa jedynie w celu asystowania koronacji oraz monarszej przysiędze, a także dla uproszenia zatwierdzenia zgodnie z panującym zwyczajem przywilejów koronnych. Oświadczyli ponadto, iż potępiają wszystkie uchwalone w okresie interregnum konstytucje oraz wszelkie postanowienia przyjęte wówczas bez ich zgody.

Memoriały z podobnymi zastrzeżeniami ułożyli również arcybiskup gnieźnieński i biskup kujawski. W. Laureo sporządził z nich jeden dokument i 19 marca zalecił przedstawić go królowi jako stanowisko nie tylko wszystkich biskupów, lecz całego duchowieństwa. Najistotniejszy argument, którym szafowano $\mathrm{w}$ memoriale, stanowiło stwierdzenie nieprawomocności konstytucji uchwalonych w okresie bezkrólewia, a także aktów prawnych, na które nie wszyscy wyrazili zgodę. W związku z tym proszono króla, by potwierdził w dawnej formie wcześniej obowiązujące prawa. W wyniku tych działań ustalono. iż dziesięć dni później na forum senatu sprawa monarszego zatwierdzenia dawnych przywilejów zostanie przegłosowana.

Z powodów zdrowotnych Uchański nie przybył na odbyte 29 marca posiedzenie senatu, w związku z czym wprowadził zmiany $\mathrm{w}$ formie memoriału. Poprawiony dokument wraz z poleceniem udania się na obrady wręczył scholastykowi krakowskiemu - Dąbrowskiemu. Podczas posiedzenia Dąbrowski odczytał memoriał dwukrotnie: najpierw w charakterze protestu przeciw postulatom posłów ziemskich, następnie zaś jako wotum arcybiskupa gnieźnieńskiego.

Za sprawą namowy nuncjusza trzy dni później prymas, pomimo choroby, kazał zanieść się do obradujących senatorów. Znalazłszy się pośród nich upomniał monarchę o konieczności obrony wyznania katolickiego. Następnie polecił swojemu sekretarzowi odczytanie nowej protestacji przeciwko zmianom w dyplomie zatwierdzającym przywileje koronne. Różnowiercy odpowiedzieli groźbami pod adresem prymasa, jednocześnie go wyśmiewa-

${ }^{26}$ Andrzej Wapowski - podkomorzy sanocki i kasztelan przemyski, zamordowany przez Samuela Zborowskiego 24 lutego 1574 r. 
jąc. Rozpuścili także fałszywe pogłoski o jego śmierci. Ponadto zaszantażowali arcybiskupa, iż zrealizują swoje groźby w wypadku jego ponownego pojawienia się w senacie.

W tym czasie kolejny przeciwnik tolerancji wyznaniowej - biskup Karnkowski, opuścił Kraków nie chcąc narazić się na podobne szykany. Pomimo niesprzyjających okoliczności arcybiskup gnieźnieński, choć wystraszony postępowaniem protestantów, szukał rady i poparcia u mazowszan.

Duchowym oparciem dla Uchańskiego był nuncjusz apostolski. Pod jego wpływem prymas pozostał konsekwentny i 19 kwietnia zjawił się ponownie na posiedzeniu senatu. Naciskał wówczas na Henryka Walezego, by zaprzysiągł prawa w takim kształcie, w jakim zatwierdzali je dwaj ostatni królowie z dynastii Jagiellonów. Postulat ten został zrealizowany 22 kwietnia. Dwa dni później obrady sejmu koronacyjnego dobiegły końca ${ }^{27}$.

Analiza materiału źródłowego pozwoliła na skonstruowanie bardzo szczegółowego opisu. Możliwa okazała się nie tylko rekonstrukcja wydarzeń od elekcji Walezego do zakończenia obrad sejmu koronacyjnego, lecz także odzwierciedlenie atmosfery trwającej wówczas walki o uprawomocnienie zawartych w akcie konfederacji generalnej warszawskiej postanowień o tolerancji wyznaniowej. Czytając źródła, można poczuć napięcie towarzyszące tej batalii oraz poznać poglądy i motywy działania poszczególnych jej uczestników. Pierwsza rzecz, na którą należy zwrócić uwagę, to fakt, iż stanom Rzeczypospolitej bardzo zależało na tym, aby elekt jeszcze w Paryżu powtórzył przysięgę złożoną w jego imieniu przez francuskie poselstwo. Zawarta w instrukcji danej delegacji polsko-litewskiej groźba wypowiedzenia posłuszeństwa wskazuje jak bardzo przedstawiciele stanów politycznych byli zdeterminowani. Nic dziwnego, ponieważ dałoby to większą podstawę prawną dla wypracowanego porozumienia, także dla artykułów o tolerancji religijnej. Mniejszą podstawę prawną już bowiem mieli za sprawą przysięgi złożonej przez deputację Monluca.

Byli tego świadomi członkowie poselstwa do Paryża, nawet jego przewodniczący - Adam Konarski, będący przeciwnikiem tolerancji wyznaniowej. Warto $\mathrm{w}$ tym miejscu podkreślić rozważne postępowanie biskupa poznańskiego i fakt, iż chciał osiągnąć zamierzony cel zgodnie z prawem. Świadczą o tym liczne wątpliwości nakreślane przez niego Uchańskiemu oraz Commendonemu. Jakże odmienna była jego postawa od tej, którą prezentowali prymas i nuncjusze apostolscy! W dążności do celu zdawali się oni gotowi na wszystko, nawet na obejście oraz ignorancję posiadanych przez zwolenników tolerancji podstaw prawnych.

${ }^{27}$ E. Dubas-Urwanowicz, dz. cyt., s. 315. 
Dla wielu najważniejsze okazało się jednak utrzymanie pokoju wewnętrznego. I to właśnie ich rozsądne myślenie zwyciężyło rozegraną przed koronacją Henryka Walezego batalię o konfederacje warszawską.

\section{BIBLIOGRAFIA}

\section{Źródła drukowane}

Bielski J., Kronika polska Marcina Bielskiego. Księgi VI Interregnum, T. XVIII, cz. 6, Warszawa 1632.

Diariusz poselstwa polskiego do Francji po Henryka Walezego w 1573 roku, oprac. A. Przyboś, R. Żelewski, Wrocław-Warszawa-Kraków 1963.

Wierzbowski T., Uchańscjana czyli zbiór dokumentów wyjaśniających życie i działalność Jakuba Uchańskiego arcybiskupa Gnieźnieńskiego, legata urodzonego, Królestwa Polskiego prymasa i pierwszego księcia, t. 3, Warszawa 1890, t. 4, Warszawa 1892.

\section{Opracowania}

Dubas-Urwanowicz E., Koronne zjazdy szlacheckie $w$ dwóch pierwszych bezkrólewiach po śmierci Zygmunta Augusta, Białystok 1998.

Grzybowski S., Henryk Walezy, Wrocław 1985.

Konopczyński W., Dzieje Polski nowożytnej, Warszawa 2003.

Korolko M., Klejnot swobodnego sumienia. Polemika wokół konfederacji warszawskiej w latach 1573-1658, Warszawa 1974.

Korolko M., Tazbir J., Konfederacja warszawska 1573 roku. Wielka karta polskiej tolerancji, Warszawa 1980.

Maciuszko J.T., Konfederacja warszawska 1573 roku. Geneza, pierwsze lata obowiq̨zywania, Warszawa 1984.

Pliński T., Bezkrólewie po Zygmuncie Auguście i elekcja króla Henryka, Kraków 1872.

Płaza S., Wielkie bezkrólewia, Kraków 1988.

Salmanowicz S., Konfederacja warszawska 1573, Warszawa 1985.

Tazbir J., Dzieje polskiej tolerancji, Warszawa 1973.

Tazbir J., Państwo bez stosów. Szkice z dziejów tolerancji w Polsce XVI i XVII w., Warszawa 2009.

Tazbir J., Reformacja, kontrreformacja, tolerancja, Wrocław 1999.

Tokarczyk A., Tolerancja, Warszawa 1978.

Tomkiewicz S., Król Henryk Walezy a Zborowscy. Szkic historyczny, Tarnopol 1880.

Urban W., Epizod reformacyjny, Kraków 1988.

Wierzbowski T., Jakub Uchański arcybiskup gnieźnieński (1502-1581), Warszawa 1895.

Wisner H., Rozróżnieni w wierze. Szkice z dziejów Rzeczypospolitej schyłku XVI i połowy XVII wieku, Warszawa 1982. 


\section{Kornelia Wasiak}

\section{FIGHTING TO SWEAR THE WARSAW CONFEDERATION FROM MAY $17^{\text {TH }} 1573$ TO APRIL $22^{\text {TH }} 1574$ IN THE LIGHT OF "DIARIUSZ POSELSTWA POLSKIEGO DO FRANCJI" TO HENRY III IN 1573}

\footnotetext{
$\mathrm{T}$ he article is a reconstruction of one of the stages of the struggle to include in the formal and legal framework the provisions on religious tolerance contained in the act of the general Warsaw confederation, written in 1573. It covers the time from the election of Henri de Valois (11 May 1573) to the end of the king's coronation parliament (24 April 1574). The article consists of three parts. The introductory fragment outlines its purpose and also contains information about sources and literature. The elaboration describes particular events related to the fight for religious tolerance along with the accompanying atmosphere as well as the motives and way of work of individual participants in these events. The end of the text contains conclusions based on the description.
}

Keywords: Warsaw Confederation, religious tolerance, Henri de Valois, Catholic Church, Polish-Lithuanian Commonwealth. 